\title{
The Image of Talented Scholar, Beauty and Love in Vietnamese Nom Narrative Poetry
}

\author{
Guojian Xun, Pham Quynh Son \\ College of Chinese Language and Literature, Hunan University, Changsha, China \\ Email: quynhson2510@yahoo.com
}

How to cite this paper: Xun, G.J. and Son, P.Q. (2017) The Image of Talented Scholar, Beauty and Love in Vietnamese Nom Narrative Poetry. Open Journal of Social Sciences, 5, 238-250.

https://doi.org/10.4236/jss.2017.55017

Received: April 21, 2017

Accepted: May 20, 2017

Published: May 23, 2017

Copyright $\odot 2017$ by authors and Scientific Research Publishing Inc. This work is licensed under the Creative Commons Attribution International License (CC BY 4.0).

http://creativecommons.org/licenses/by/4.0/

\begin{abstract}
The emergence and prevalence of Nom narrative poetry associated with the decline of feudalism in Vietnam. The feudal system began to weaken since the 16 th century and the 18th century became severe, and mid-19th century entered the crisis period. Social contradictions, class contradictions brought huge differentiation inside the ruling class which had brought a large part of writers, poets closer to people. Overcoming class ideology, those intellectuals had represented the aspirations of the times, the voice of the people with all their hearts. Humanism literature is the result of that social struggle and ideological struggle process. Along with the development of Nom letter and the sin-eight-word, the Nom first poems were formed and developed that way. Nom narrative poetry about "talented scholar and beauty" told the story of love between a man and a woman. They were not only outstanding in their appearance but also faithful in love. To protect their love, they had to overcome the resistance of feudal rites, the harm of those mean people, and they even had to look for the death to keep a vow with their lovers. All those things had made up the beauty of Nom narrative poetry. That also explains why Nom narrative poetry was soon welcomed socially and had such huge influence on Vietnamese's life. However, in field of literature research, there has not been a unified notion of Nom narrative poetry about talented scholar and beauty. Therefore a viewpoint about the notion of Nom narrative poetry will be discussed. Moreover the writer also analyzes the talented scholars, the beauties and their love. As a result, the value of this type of poetry in Vietnam national literature will be affirmed.
\end{abstract}

\section{Keywords}

Nom Narrative Poetry, Talented Scholar, Beauty, Love

\section{Introduction}

Regarding the concept of Nom narrative poetry, opinions from several research- 
ers and scholars such as Duong Quang Ham, Dang Thanh Le, Le Ba Han, Tran Dinh Su, Nguyen Khac Phi were considered. In "Vietnam van hoc su yeu", Duong Quang Ham said "Nom narrative poetry is novels written in the sineight-word and its variant". Dang Thanh Le, in "Truyen Kieu va the loai truyen Nom" defined Nom narrative poetry as "novels of narrative form written in sineight-word with Nom letters" [1]. Meanwhile, Le Ba Han, Tran Dinh Su and Nguyen Khac Phi conceptualized Nom narrative poetry in " Tu dien thuat ngu van hoc" as "long poems in narrative form, which blossomed in the end of $18^{\text {th }}$ century and early $19^{\text {th }}$ century. Being written in Vietnamese, they are called Nom narrative poetry" [2].

Although their wording was sometimes different, those researchers share similarities when defining "Nom narrative poetry". And we all agree with Ngo Thi Thanh Nga's definition of three basic components of Nom narrative poetry in her paper "Hoa Tien ky trong mach truyen Nom bac hoc the ky XVIII-dau the ky $X I X$ ", which "Nom narrative poetry is a genre of narrative form, usually written in sin-eight-word with national language (Nom)".

In terms of their contents, those poems exploited the love story of a talented male student with a beautiful daughter from a wealthy family. The story consists of three parts: 1) love at first sight, 2) the harm from mean people and 3) reunion after the man's success in career.

There has not been currently an identical name for "talented scholar and beauty Nom narrative poetry". However, from what has been done, we assume "talented scholar and beauty Nom narrative poetry" are a genre which digs deeply the love story between two talented youths from two different family backgrounds. They are real people, not a product of imagination in legendary. Vietnamese talented scholar and beauty Nom narrative poetry can be divided into two groups. The first are some borrowed ones from Chinese literature such as “Truyen Song Tinh”, “Truyen Hoa Tien”, “Truyen Kieu”, “Nhi do mai”, "Hao cau tan truyen", "Truyen Phan Tran". The others are Vietnamese originated stories, namely "So kinh tan trang", "Luc Van Tien”, “Mong Hien truyen", "Van Trung Nguyet Kinh tan truyen", "Chau so kim kinh luc" [3].

\section{Talented Scholar}

As a matter of fact, Vietnamese society during feudalism highly valued the socalled "similar background between two families" in marriage life. During feudalism, marriage was considered one way to maintain family lineage, which resulted in this saying: "Marriage is to tighten the mutual relationship between two families, in which the older worship the ancestors, and the younger give birth to later generation". Moreover, getting married played a crucial role in selecting the appropriate heirs of a family's legal properties and belongings. Traditionally, Vietnamese people had always attached great importance in finding a suitable partner for their children at right age, which consolidated the relationship between two families rather than respecting the love and care of the couple. Therefore, getting married had had political aim which benefited the 
family members. Obviously, the most important factor of a marriage was the families' benefits instead of the willingness of the two people. The typical feature of society at that time was privatization leading to the fact that getting married was mainly for the sake of family members [4]. Therefore, marriage in feudalism highly appreciated the "similar background between two families", which generated big gap between the rich and the poor.

However, during the period when "Nom poetry" tremendously developed, the standard for young people to get married was the love between them rather than similar background. Furthermore, it was often the case of a poor male student falling in love with a noble lady who had brilliant family background as well as extraordinary beauty and talent. Why did those ladies fall in love with those poor male students? What was those students' special skill and spirit?

\subsection{Poetical Talent and Exam Report}

In terms of personal qualities, the he-men possessed extremely high intellectual faculties which were shown at young age. Some of the typical examples of those were Song Tinh in 'Truyen Song Tinh", Pham Kim in "So kinh tan trang" and To Huu Bach in "Ngoc Kieu Le". They were very talented and skillful in poetry and prose who could generate their own products promptly. To Huu Bach in "Ngoc Kieu Le" was described that:

Truơng rằng: “Đã biết mùi huoong,

Gập đây thư họ một chuong thẹn gi?"

Đrợc nhời mơn mởn tay đề,

Bút hoa một vẫy, thủ thi đã rồi.

Thấy chàng tài mẫn lạ đời,

Cà̀m thi ngâm ngợi tưởng người thanh tao.

Biết đâu chí rộng tài cao,

Nhin ra nét tốt, đọc vào miệng trơn.

Vương rằng: "Này đáng bạn lan,

Luõ̃ng hùng ron ruổi tao đàn còn al!"

Sinh rằng: "Đâu được nhu lò̀i,

Đứng vào nguyên xướng còn vài lần sân [5].

Meaning

Truong Quynh Nhu said: I've heard about you for a long time.

Now I have a chance to meet you, which makes me want to construct a poem.

To Huu Bach readily agrees when hearing about that.

The pen has already been put, a poem has been made.

Seeing the talented man plucking the strings and declaiming his poetry with an aura of an unworldly beauty, which shows his considerable knowledge

Vuong Khanh says. He deserves to be a like-minded partner.

No one can compose poems better than him.

To Huu Bach says. No, I'm not as good as lots of other people. 
In the above-mentioned verse, from To Huu Bach's modest words and Vuong Khanh's astonishment, the talent of the main character is clearly shown. Despite his poverty, he can still steal the heart of the young lady from a rich family.

Actually in the feudal society with the heavy concept of suitable alliance, the rich and the poor can rarely had family connection with each other, as the rich was strongly affected by the concept of the social stratum. However, talented people in this kind of novel always put the factor of talent as the first standard when choosing their companion for life, regardless of the concept of the social stratum. In "Ngoc Kieu Le", the main female character Bach Hong Ngoc denied to marry an ordinary man. Supposing he was an elegent gentlement who was more well-educated than her, he could have a chance with her. Lu Mong Le even demanded a higher academic level of her future partner. She considered this element the most important to choose a husband. In order to meet the dream man To Huu Bach, she even ignored the feudal rites, disguised as a man and escaped from her zenana just to meet him. The men's talents in poetry and writing was clearly expressed in the poems. On the one hand, the authors had a high opinion of uprightness of the talented man who relied vaingloriously on their geniuses and neglected social affairs. On the other hand, their talent in making poems also gained a lot of attention. The talented men were favoured by beautiful women, functioning as a bridge connecting them. Nevertheless, their true talents were all assessed through their results in different examinations. In fact, the authors built characters' talents in writing to help readers understand why they had good results in these examinations.

In these poems, the talented men were often handsome, well-educated and the difficult examinations could not trouble them. Besides their outstanding ability in writing and poetry, beautiful women in such poems also attached great important to good results in examinations that were a must-have condition if these talented men wanted to marry them. Hence, social position and fame were the best way to link talented men with the women of their dreams. As Nhuy Chau in “Truyen Song Tinh" advised Song Tinh:

Hãy tua đăng hoa gia công

Chỉ ngày nhảy bến hóa rồng cuớp biêu.

Bấy giờ ghe nỗi ơn yêu

Dầu lòng chàng lại xuy tiêu phuợng đải [5].

Meaning:

You should focus on studying

Until you get good results

Then we may fall in love late

And you can marry me.

It can be seen that the differences in family conditions are the main concerns of the relationship between the talented men and beautiful women. However, the talent was not enough, only when they could get good results in examinations 
and eventually became persons of wealth and high social status, they could marry the women of their lives. Of course, most of such poems had happy endings, so we could see how high the expectation and admiration of the author to wealth and standing are.

The motif of these novels is quite similar. After achieving wealth and social status, the talented men and beautiful women would marry each other, which makes readers psychologically satisfied. The authors put a great amount of efforts on building this motif, as each novel expressed their admiration to the main characters. We can assume that wealth and social status were highly appreciated, but they did not have much effects on their true feelings. In other words, the fact that they sought for richness was their active attitudes and ways to the brighter future.

\subsection{Bravery}

Main characters in this kind of poetry changes from handsome students to brave gentlemen. Representatives for such figure is Tu Hai in "Truyen Kieu". By describing his appearance and actions, the author showed us a new kind of the talented men.

First of all, Tu Hai's appearance was typically built like heroes in that time with a wide shoulder and a muscular body. Furthermore, Nguyen Du even made verses describing him:

Râu hùm, hàm én, mày ngài,

Vai năm tấc rộng, thân muời thước cao [5].

Meaning:

He has epic beard like tiger's, broad jaw like swallow's and bushy eyebrows like silkworms.

His shoulder was five inches wide and his height measured ten metres.

In addition to his appearance, Tu Hai showed the heroic standard through his love and bravery. Firstly, he expressed his care to his beloved woman. He did not despised Thuy Kieu, instead he adored her beauty and personality. After achieving success in his own career, he helped Kieu to revenge on those who had caused harm to her. Secondly, he also had an indomitable will of a hero who wanted to travel round the world. He was described in two verses:

Nửa năm hương hỉa đương nồng

Truợng phu thoắt đã động lòng bốn phuoong [5].

Meaning:

A half of a year together, we are still in passionate love for each other,

But you want to go round the world.

Furthermore, even when he lost the battle and also his life, he still stood boldly and did not afraid of the death: 


\section{Khí thiêng khi đã về thần}

Nhơn nhơn còn đứng chôn chân giũa vòng [5].

Meaning:

When he dies,

He still stands tall and proud in the encirclement of the enemy.

These words did satisfy readers. The heroic character was lively expressed in this kind of novel that built a new kind of gentleman replacing the images of the talented but weak men. The heroic characters were also created in many other poems, such as Thiet Trung Ngoc in "Hao cau tan truyen", Luc Van Tien in "Truyen Luc Van Tien", etc.

Through the author's applause, it is obvious that there had a great change in ideas of the contemporary society from "all things are humble except reading books" to the approvement to other kinds of talent.

\section{Beauty}

Nom narrative poetry of talented scholar and beauty refers that only the women who have beautiful appearance, good nature, and outstanding ability are the ideal images of talent and virtue men. The ideal husband of the main woman character presented in the last chapter is the talent man who has a basket of Shu Ching, thorough comprehension of ancient a modern learning; better poetic words than anyone, sets pen to paper as God. According to the point of view of talented men and beautiful women, beauty has not only good-looking appearance but also meticulous comprehension of literature, outstanding refined talent. As a result, they might be a well-matched couple. It is noticeable that the ancients and modern people have the same explanation of the relationship between moral self-improving and spiritual beauty. It means that the internal beauty is more highly evaluated than physical beauty. This also is the aspect which is specially emphasized in the writings belonging to the novel type of "talented scholar and beauty".

\subsection{Countenance Beauty}

In the progress of human history, the subject that has created the society is men. Also, the love and marriage is the thing referred to from the time immemorial of the human; and the topic which the human has praised and exclaimed. The mankind usually pursues the true, the good and the beauty and turns towards the best things. In the length of history, one incessantly has sought a deal marriage model for oneself. At the end of Ming dynasty and the beginning of Qing dynasty in China, to be under influence of romantic trend and people liberation movement, the notions of human value had changed. A group of authors composed a great number of poetry of "talented scholar and beauty", in which perform completely a new particular feature, and criticize the traditional conception of the love and union. This is mainly expressed through the way which the beauty's inner feelings are shown. The beauty character in the talented 
scholar and beauty novel has more beautiful countenance than others, so the talented young man often falls in love her at the first sight. In the tale of Kieu, Thuy Kieu and Thuy Van are portrayed as follow:

Mai cốt cách, tuyết tinh thần

Mỗi người một vẻ, muời phân vẹn murò̀i.

Vân xem trang trọng khác vời

Khuôn trăng đầy đặn, nét ngài nở nang

Hoa cuời, ngọc thốt, đoan trang

Mây thua muớc tóc, tuyết nhwờng màu da

Kiều càng sắc sảo mặn mà

So bề tài sắc lại là phần hơn

Làn thu thủy, nét Xuân sơn

Hoa ghen thua thăm, liễu hờn kém xanh. [5]

Meaning:

With their high personality and their pure minds,

Each one her own manner, both perfectly refined.

Vân looked sedate with her distinguished grace,

Her large eyebrows and her full-moon face.

Flowers bloomed in her sweet smile so nicely,

Pearls resounded in her sober voice so mildly.

Clouds couldn't match her smooth hair in undulation.

Snow would yield up to the freshness of her complexion.

Kiều looked keener in her charm and undoubtedly

She surpassed her sister both in talented scholar and beauty,

With her eyes so bright as Autumn water shimmering,

And her eyebrows so fresh as young mountains in Spring.

Nice flowers would envy her charming lips' freshness,

Willow leaves'd get angry with her eyebrows' greenness.

The glamour of Thuy Van is that of a "correct and decent"/"sober mildly" young unmarried woman who is "sedate with her distinguished grace". Her "full-moon" face is compared with the light and full moon. Her voice is mildly sounded as pearls. What may be more beautiful than her hair and skin colour as outlined: Clouds couldn't match her smooth hair in undulation. Snow would yield up to the freshness of her complexion. The author used the symbolic agreement style of writing to describe the beauty of Thuy Van, in which creates full-emotionally metaphorical illustrations. Nguyen Du used skillful depiction which aims to define that Thuy Kieu's is first-class beauty. He wrote about Kieu's look "Her single glance might even shake the Royal Castle. Her single smile could even make the Nation tremble". Her eyes are pictured as bright as autumn water, and her eyebrows are likened so pretty as young mountains in spring. She is so lovely that Nice flowers would envy her charming lips freshness, Willow leaves'd get angry with her eyebrows' greenness. Nguyen Du's 
pen is versatile and various which is fantastically combined metaphor, personification, overstatement with old materials of poetry (e.g. shake the Royal Castle, make the Nation tremble), so makes wonderful verses. Beauty silhouette is outlined by few conditioning sketchy lines, but so miraculous that it might leave readers' deep emotion and honour [6].

Like the young lady namely Nhuy Chau in "Dinh tinh nhan":

Đặt tên nàng gọi Nhụy Châu

Hoa xuân thức ánh, nguyệt thu vẻ bày [5].

Meaning:

To give her a name called "Nhuy Chau"

With her face so sunny as flowers of Spring, and her look so bright as the moonlight of Autumn.

When the young lady Nhuy Chau comes near Song Tinh, his mind is right distraught by her beauty as if Nhuy Chau is a fairy. He thinks to himself: "why has such a beautiful girl". Through Song Tinh's words, we can image Nhuy Chau's glamour as descended fairies.

This description is very popular in epical poems. Towards beauty is a natural attribute of human, so good-looking appearance is a good condition for male and female to get attractable each other, and a foundation for starting love. The author took a great effort to picture this glamour. Towards and being fond of the beauty proves that human's nature has been released and this is realized in the marriage conception.

In feudal society, the union is just considered as "the friendly connection between two families, the man is concerned with family temple, and the woman is concerned with having children who maintain the continuity of a family line". The major purpose of "the friendly connection between two families" or called "traditional marriage style" is to serve the benefit of whole family.

The way which the beauty of women is described in the poetry of talented scholar and beauty, has showed the negation on traditional unions. Marriage not only simply is to maintain the race of a family line, but also connects two lovers' feelings in which consist of the face beauty of each other and respect for aesthetic views of each other.

\subsection{Talent Beauty}

The statement: "females are a half of the sky" is an affirmation to society's duty and the ability of women so that their ability and intellect might be brought into play. In the feudal time, the ancients stated "women, who are talentless, are wellbehaved". It means that women do not need to have capacity and education. According to Chinese concept, an ideal female called for four attributes including industry, appearance, speech, and behavior. In the old society of Vietnam, males dominated, and females were defined as dependent on males, and so their ability and intellect was not a proud figure. 
However, in Nom narrative poetry of "talented scholar and beauty", a beauty has not only beautiful appearance but also outstanding aptitudes compared with other women. The beauty's outstanding talent is an important factor to fascinate talented young man. In the developing length of feudal society, talent of women was never interested while the poetry of "talented scholar and beauty" have set aside to depict female's talent. This is a progressive thought.

Like the character Nhuy Chau in the writing namely "Truyen Song Tinh":

Phương phi vìa thuở trâm cài

Giỏi nghề thêu dẹt, trổ tài phú tho [5].

Meaning:

Being 15 years old, her face is imposing

With her skillful embroidery and good poem and literacy composition

Or like the character Thuy Kieu in "Truyen Kieu":

Thông minh vốn sã̃n tính trời

Pha nghè̀ thi họa, đủ mùi ca ngâm

Cung, thuo'ng, làu bậc ngũ âm

Nghề riêng ăn đưt, hồ cầm một truơng [5].

Meaning:

Endowed with an inherent intelligence,

She excelled in poetry, chanting, and painting.

Well versed in pitches and fine tones of music,

She was peerless with her skill of lute playing.

Apart from music, chess, poetry and painting, there are beautys who are both a scholar and warrior, ingenious and brave. Woman general Luu is a sample of this character kind. After unjust deaths of her parents and relatives due to sycophantic courtiers' harm, she was deeply resentful. Thus, she and servants of Luu family together moved to Kinh Son to raise the standard to revolt and revenge her parents. After collecting a great number of forces, she again and again took troops to the border crossing to fight against. Her forces were always received a warm welcome and fondness of people. The court eventually handed over the sycophantic courtier who injured her parents to revenge for their wrongful death. Then, she dismissed her troops and and had the King's praise.

With regard to building such female characters, we believe that this is ideal female personalities and typical characters for contemporary intelligentsias. For most writings about talented young man and beauty, aside from beautys who have perfect ability of music, chess, poetry and painting, there are beautys who are heroes with veil, different figures becoming the leaders of an army force or masters of a mountain camp. These women could set themselves up in business, be second to men. They also are the persons who are against traditional marriage regulations, as well as the pioneers in the movements against underdeveloped feudal system. The talent beauty of beauty overcomes the standard beauty at 
which only considers the appearance beauty as the standard of women's beauty in the past literacy works. The poetry of talented scholar and beauty are focused more on the talent and intellect of beautys.

\section{The Love in Nom Narrative Poetry about Talent Scholar and Beauty}

In Vietnam's literature works, love and marriage play an important role with high frequency. However, in narrative poetry about talent scholar and beauty, these subjects have their own new characteristics. Some works express the new concept of burghers of love and marriage while some others express the contradiction between love and feudal rites. In addition, some use tragic ending to criticize the persecution of feudal rites for women or happy ending to negate feudal rites with a view to praising love between men and women.

The beauty of "love" in the poetry about beauty and talent has its own purity. Males and females characters have all three qualities of talent, beauty and morality. The relationship described is usually the poetic exchange and lust is not mentioned in those works, which helps differentiate them with erotic novels.

\subsection{Faithfulness in Love}

Both beauties and lads express their faithful hearts. "Ngoc Kieu Le" is a typical example.

Lur rằng. “Trót đã nặng lời,

Trách sao góc biển bên trời chăng theo

Nhũng là đất rộng trời cao,

Vòng trần gian cũng có nhiều giai nhân

Giá nhu lại có Văn Quân,

Lòng Tu Mã cũng có phần nào chăng?”

Sinh rằng: "Ví có ai bằng,

Thì lòng cũng trọng đến chùng ấy thôi.

Bằng nhu được một quên hai,

Lòng này thề chẳng nhu ai phu lòng" [5].

Meaning:

Lu Mong Le said: We have made a vow

However I cannot be with you

The world is big

And there are many beautiful girls

If a beautiful girl like Văn Quân appears

Will you change your heart like Tu Mã?

Tô Hĩu Bạch replied: If any

I will just respect

I will never forget you

I vow to keep my promise.

We can see the faithfulness Lu Mong Le and To Huu Bach shared on the basis 
of their conversation. However, boastful or exaggerative sentences such as "I will not change my heart until the ocean dries and the rock erodes away" cannot be seen in that separation. Just simple sentences like "phải ngươi được ván bán thuyền hay sao" can convey his faithful heart. When Lu Mong Le wants to find out what To Huu Bach would do if another girl appeared and he said he would not change his heart.

In "The tale of Kieu”, after his uncle's funeral, Kim Trong returned and knew about the calamity of Kieu's family and that she had to sell herself to save her father. As Trong remembered what Kieu said, he took Kieu's parents and sister and took care of them. He also tried to find her everywhere. Although he knew that Kieu was lured into during her years of difficulties, he still insisted on finding her again.

Rà̀ng: "Tôi trót quá chân ra,

Để cho đến nỗi trôi hoa, dạt bèo.

Cùng nhau thề thốt đã nhiều,

Nhũng điều vàng đá, phải điều nói không?

Chư chăn gối cũng vợ chồng,

Lòng nào mà nõ dít lòng cho đang?

Bao nhiêu của, mấy ngày đàng,

Còn tôi, tôi gặp mặt nàng mới thồ?" [5]

Meaning:

“Trong said: due to my carelessness, she had those miseries

We have made vows which cannot be empty words

Although we have not been married, I consider her my wife.

How can I forget her

No matter how much time and money will I have to spend

I insist on finding her!"

Kieu Nguyet Nga, a girl from Ha Khe, just met Luc Van Tien once but she missed him so much. The image of the lad on her mind was so deep that made a statue of him and kept it with her in order not to miss him as much and engraved his saving her life. When she was notified that Luc Van Tien died, she vowed to worship the statue all her life.

\subsection{Saving the Purity in Love}

Nom narrative poetry about talented scholars and beauties mainly describe young male and females with three characteristics, including talent, beauty and morality. They get to know and esteem each other while composing and enjoying poems together. On the traditional perspective, they create a match made in heaven. However, in the real life, the filthy people deliberately intend to separate them. Finally the bad ones are not successful. The main male and female characters not only overcome the challenges together without braking any code of behaviour, but finally get married as well. They maintain the purity for the other 
despite the fact that they may have to die for that.

Pham Kim and Quynh Nhu in "So kinh tan trang" are children of two families with long lasting good relationship. A talented young man and a beautiful girl create a nice couple. Since they esteem the other's poetic competence, they fall in love with each other and make a vow to get married. They seem to live happily together when the troubles come. A commander-in-chief in the capital city is heard about the beauty of Quynh Nhu and wants to marry her. Truong Cong family do not want to marry their daughter to him, but he has to agree due to the pressure from the powerful man. As she knows, Quynh Nhu wrote a letter to Pham Kim and ask him to come and talk. Do not know what to do; they both vow to get married in the next life. Before say goodbye, Quynh Nhu raises her hand with two words "Quynh Nuong" to show her faithfulness. She kills herself after going home. Pham Kim is so suffering that he gets seriously ill. After his recovery, he goes into a church in order to relieve his sufferings.

Like Quynh Nhu, Hanh Nguyen in "Nhi do mai", on the way she pays tribute to Hu country, she drowns herself to keep her virginity.

\section{Mới hay trời với giai nhân \\ Được riêng chũ tiết, nắm phần chũ danh \\ Làm cho chán nỗi thỉ thanh \\ Trải qua bao nạn móri dành phúc sau [5]. \\ Meaning: \\ I know that heaven treats beautiful girl \\ It does not allow her name and her virtue to be complete \\ There are also many challenges to overcome \\ Then she will be happy.}

Unlucky like Quynh Nhu and Hanh Nguyen who are saved by gods and can reunite with their lovers, Thuy Kieu in "Truyen Kieu" keeps her love and purity in an absolutely different way. After 15 years, she meets Kim Trong again, Kieu refuses to live a marriage life with him although Trong says he sympathizes with her situation. Trong says Chũ trinh kia cũng có ba bảy đương (virginity can be understood in different ways) [7]. However, Kieu just suggests a friendship with him. Since she does not feels she deserves to be his wife. In her opinion, getting married with him also means treating him badly. She has won through the sexual temptation of Kim Trong and keeps the virginity for the first night of their marriage life. This time she saves it because she thinks sexuality does not make sense in her life with Kim Trong.

\section{Conclusions}

In Nom narrative poetry, talented scholars are not only the men of great learning and knowledge, but also were the men who courageously took part in battles; and for the beauties, they are those with not only beautiful and charming appearance, outstanding talent, expertise in literature, but they also represent 
amorous females who have the concept that love is the base of marriage, which creates a special appeal. In the works about the consistent and pure love, talented scholars and beauties have to challenge many difficulties. They have to be drifted everywhere, fall into misery, be harmed by filthy people and get married under duress. However they have never surrendered. Most of them can finally get married, which creates a happy ending for a difficult love affair.

By analyzing the talented scholars, the beauties and their love, we see not only the beauty of their physical appearance, internal beauty, and their talents, but also the distractions and apposition of ordinary Vietnamese people against feudalism. In addition, with the typical happy endings, writers, on behalf of the public, express their desire for an escape from the constraints of feudalism, towards the beauty free love. This also represents the ideological liberation and social advance in Vietnam during that time.

\section{References}

[1] Hoach, K.T. (2007) Nom Story: History of Development and Type of Literature. Education Press, Hanoi.

[2] Han, L.B., Su, T.D. and Phi, N.K. (1992) Dictionary of Vietnam Literature Term. Education Press, Hanoi.

[3] Khanh, D.G., Tan, B.D. and Chuong, M.C. (2010) Vietnam Literature. Education Press, Hanoi.

[4] Ham, D.Q. (2005) Simplified History of Vietnam Literature. Youth Press, Hanoi.

[5] Tan, B.D. (2009) Vietnam Acient Literature Intergration. Education Press, Hanoi.

[6] Le, D.T. (1979) Kieu Story and the Type of Nom Story. Social Science Press, Hanoi.

[7] Anh, D.D. (1975) Nom Letter: Source, Structure, Development. Social Science Press, Hanoi.

\section{Scientific Research Publishing}

Submit or recommend next manuscript to SCIRP and we will provide best service for you:

Accepting pre-submission inquiries through Email, Facebook, LinkedIn, Twitter, etc. A wide selection of journals (inclusive of 9 subjects, more than 200 journals)

Providing 24-hour high-quality service

User-friendly online submission system

Fair and swift peer-review system

Efficient typesetting and proofreading procedure

Display of the result of downloads and visits, as well as the number of cited articles

Maximum dissemination of your research work

Submit your manuscript at: http://papersubmission.scirp.org/

Or contact jss@scirp.org 